\title{
不規則地震動に対する構造物の最大応答の 推定法について*
}

\author{
ON ESTIMATION OF THE MAXIMUM RESPONSE OF STRUCTURES \\ SUBJECTED TO RANDOM EARTHQUAKE MOTION
}

\section{1. 緒論}

土木構造物に作用寸る外力の多くは時間的に不規則に 変動し，またその波形を確定関数として予測することが 困難である。地震力はその典型的な例であるが，このよ うな不規則外力に対する構造物の応答特性を把握し, そ の設計法を確立するためには, 構造物の非破壊確率 ${ }^{1}($ ( わゆるリライアビリティ関数）を求めておくことが重要 となる。非破壊確率を求めるに際しては, 外力の不規則 性のほかに, 構造物の破壞基準の設定, 構造要素および 構造系全体としての強度のばらつきなど, 多くの項目に 関する評価が必要となるが, 本研究では, その中の重要 な問題の一つとして, 不規則な地震動を受ける構造物の 最大応答の確率分布を取り扱った。

構造物または構造部材の最大応答量 (変位, 変形量, 疬力など）をある許容值以下に収めようとする設計法に おいて，構造物自体に関する物理量のばらつきを無視す 礼ば, 最大応答の確率分布はそのまま非破壊確率を表わ 寸重要な確率量であるが ${ }^{11}$, 一般にその厳密解を求める ことはきわめて困難である。したがって, 最大地震応答 の確率分布に関する従来の研究も, 結局は何らかの形で 近似解を導いているようである。この問題では, Rosenblueth と Bustamante の先駆的な研究 ${ }^{2)}$ が著名である が，そこでは地震動は white noise に限定されている。 Freudenthal と篠塚 ${ }^{3}$ は, 最大応答の確率分布の上・下 界を導いたが，それらは必ずしも実用的に十分に相接近 した值を与えていない。また山田・竹宮 ${ }^{4)} は$ は, Daven$\operatorname{port}^{5)}$, 小松 ${ }^{(6)}$ が耐風設計の問題で用いたのと同様に, 任意の時刻に㧍ける構造物の応答特性は, 過去の応答か ら独立であるとして最大応答の確率分布の近似解を求め

* 土木学会第 25,26 回年次学術講演会 (昭. 45,46 ) および 第 11 回地震工学研究発表会 (昭. 46) で発表.

** 正会員 工博 京都大学助教授 工学部交通土木工学教室
亀田弘行**

By Hiroyuki Kameda
たが，その精度については検討が行なわれていないよう である。比較的減衰定数の小さい構造物の地震応答は強 い周期性を示す結果, 相異なる時刻での応答の間には高 い相関が認められるから，かかる仮定で十分な精度が得 られるパラメーター領域はかなり限定されるものと考え るのが妥当であろら。

一般に, この種の問題のように近似解しか求め得ない 場合には，その精度を十分に検討して適用範团を明らか にすることがぜひとも必要であり,さらに単一の解法を 十分なパラメーター領域にわたって適用できない場合に は，たとえば精度の悪化する領域を相補らような複数の 解法を用意して，できるだけ高精度でかつ現象に忠実な 解析を行ないらるよう努めるのが良策であろら。このよ らな観点から, 本研究では最大応答の確率分布を求める ための二種の解法を考案した。すなわち，(1) 純出生過 程の方程式を基礎として, 相異なる時刻での応答間の相 関をできるだけ考慮する方法，および (2) 応答包絡線 の極值分布の理論を忘用する方法である。数值計算によ り精度の検討を行なった結果, これらの解法を適宜選択 適用することによって，地震動と構造物に関する諸特性 の広い範囲に対して最大地震応答の確率分布を求めうる ことを示した。さらにこれらの結果に基づいて, 最大地 震応答の確率統計的性質を考察し, それより構造物の耐 震設計への応用の手法に論及した。

本論文では，構造物の振動モデルは線形 1 自由度系に 限定したが, 最大応答の確率分布に関する解法は, 非線 形系抢よび多自由度系にも適用しうるものである。

\section{2. 地震動の確率モデル}

構造物の最大地震応答を論ずる場合には, 初期条件の 影響を無視できない場合を考慮して, 入力地震動の非定 常性をも取り入れた非定常応答を取り扱らのが妥当と考 えられる。そのために, 地震時の地動加速度 $\ddot{z}(t)$ を次 
式で表わす7),8)。

$$
\ddot{z}(t)=\beta f(t ; \tau) g(t)
$$

ここに, $\beta$ は加速度の次元を持つ定 数, $f(t ; \tau)$ は, 最 大值 1 なる正の 無次元確定関数, $g(t)$ は平均值ゼロで 分散 1 なる 無次元の 正規定常確率過程 である。 $f(t ; \tau)$ は shape function とも呼ばれ, $\ddot{z}(t)$ の振幅強度の非

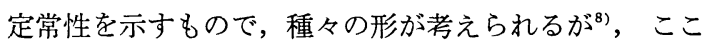
では次式 ${ }^{3)}$ を採用する。

$$
f(t ; \tau)=\frac{(1+\xi)^{(1+1 / \xi)}}{\xi} e^{-s t}\left(1-e^{-\xi s t}\right)
$$

ここに, $\xi, s$ は $f(t ; \tau)$ の形を決めるパラメーターで あり, $\tau$ は後述の等価継続時間である。式 (2) の $f(t$; ๘) は,

$$
t=t_{m}=\frac{1}{s \xi} \log (1+\xi)
$$

で最大值 1 となる。Fig. 1 にこのような $f(t ; \tau)$ の例 を示した。

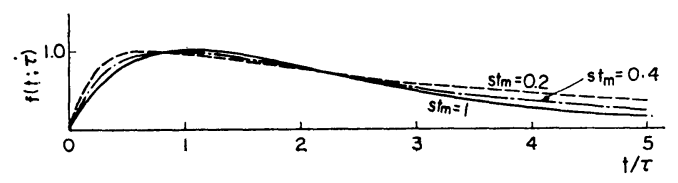

Fig. 1 Shape Function $f(t ; \tau)$ of Earthquake Motion.

かくして設定された不規則地震動の継続時間を次のよ らに定義する。すなわち, 式 (1) で表わされる地動 $\ddot{z}(t)$ が, 分散 $\beta^{2}$ なる定常確率過程 $\beta g(t)$ から時間 $\tau$ の部分を切出したものと最大加速度 $\alpha$ の期待值 $\alpha_{m}=$ $E[\alpha]$ を等しくする場合, この $\tau$ を $\ddot{z}(t)$ の等価継続時

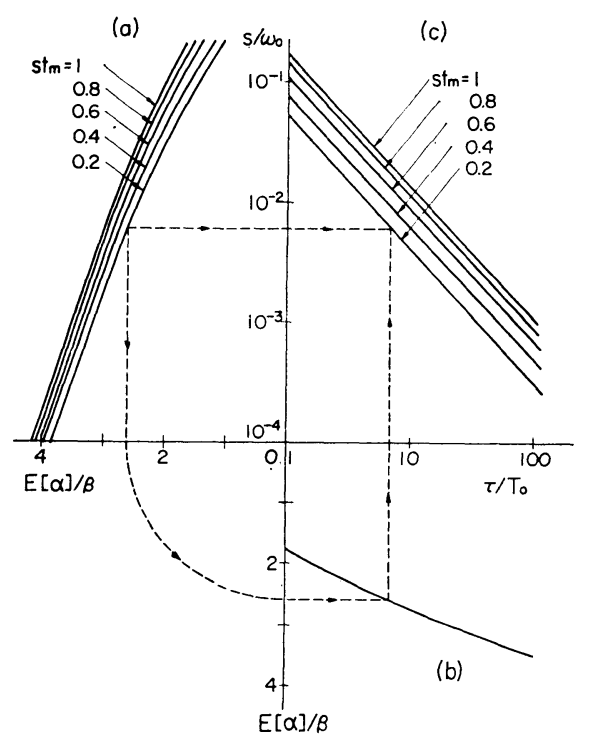

Fig. 2 Determination of the Equivalent Duration of Earthquake Motion.
間とする。これを求める手順を Fig. 2 に示した。著者 らはさきに, 比較的広帯域の確率過程である地震動の最 大加速度を求める解法を論じたが7), Fig. 2 (a) はその 方法によって式 (1) で与えられる 地動の最大加速度の 期待值 $E[\alpha]$ を求めた結果であり, Fig. 2 (b) は, 同 様の方法から求めた定常過程 $\beta g(t)$ の $E[\alpha]$ である。 いずれの場合にも $g(t)$ のスペクトル密度には文献 7) と同じ形を用いており， $T_{0}$ は卓越周期， $\omega_{0}$ は卓越円振 動数である。これらの結果から， $\ddot{z}(t)$ の等価継続時間 $\tau$ とパラメーター $s, t_{m}$ (式 (3) によって $\xi$ ) との関係 が Fig. 2 (c) のように求められる。同図から，s/ $\omega_{0}$ と $\tau / T_{0}$ の間には次のような関係があることがわかった。

$$
s / \omega_{0}=C\left(\tau / T_{0}\right)^{-1.09}
$$

ここに, C は Ta-

ble 1 に示される定 数である。本論文で は, すべて $s t_{m}=$ $0.4, \xi=4.047, C=$ 0.077 を用いる。

構造物の応答解析

では，入力のスペク

Table 1 Parameters to Characterize the Shape Function.

\begin{tabular}{c|c|c}
\hline$s t_{m}$ & \multicolumn{1}{|c|}{} & $C$ \\
\cline { 2 - 3 } 1.0 & 0.0 & 0.166 \\
0.8 & 0.539 & 0.136 \\
0.6 & 1.579 & 0.108 \\
0.4 & 4.047 & 0.077 \\
0.2 & 13.30 & 0.050 \\
\hline
\end{tabular}

トル密度のピークの高さを独立なパラメーターで自由に 調節できるのが望ましい。以下の解析では $g(t)$ のスペ クトル密度として次式を用いる。

$$
S_{g}(\omega)=\frac{4 h_{0}}{\pi \omega_{0}} \frac{\left(\omega / \omega_{0}\right)^{2}}{\left\{1-\left(\omega / \omega_{0}\right)^{2}\right\}^{2}+4 h_{0}{ }^{2}\left(\omega / \omega_{0}\right)^{2}}
$$

ただし， $\omega_{0}$ は卓越円振動数である。式 (5) の $S_{g}(\omega)$. は, white noise に対する線形 1 自由度系の相対速度応 答のスペクトル密度に相似であって, $h_{0}$ はその場合の減 衰定数に相当するが，ここではそのような物理的なアナ ロジーではなく, 式 (5) によれば $S_{g}(0)=0$ となり, また $\omega=\omega_{0}$ で最大值 $S_{g}\left(\omega_{0}\right)=1 /\left(\pi h_{0} \omega_{0}\right)$ となることか ら同式の形を採用する。本研究では, 後述の平均応答ス ペクトルの形状などから，すべて $h_{0}=0.9$ とするが， この值はあくまで暫定的なものであり, 実際には種々の 地震動の特性によって変化すべきものである。

式 (5)の $S_{g}(\omega)$ を用いると, Fig. 2 の $E[\alpha]$ を求 める際に $\omega$ に関する積分が発散するという問題が生ず るが7), これは構造物の応答を解析する過程で解消する 性質のものであるので, ここでは簡単のため, 等価継続 時間 $\tau$ の算定にはすべて Fig. 2 を用いることにする。.

\section{3. 線形 1 自由度系の r.m.s. 応答および応答間 の相関係数}

構造物が線形 1 自由度系で表わされる場合には, 地動, 加速度 $\ddot{z}(t)$ に対する構造物の相対変位応答 $y(t)$ は, 
倜知のように次式で与えられる。

$$
y(t)=-\frac{1}{\bar{\omega}_{n}} \int_{0}^{t} h\left(t-\tau^{\prime}\right) \ddot{z}\left(\tau^{\prime}\right) d \tau^{\prime}
$$

ただし，

$$
h(t)=e^{-h_{n} \omega_{n} t} \sin \bar{\omega}_{n} t, \bar{\omega}_{n}=\sqrt{1-h^{2}{ }_{n}} \omega_{n}
$$

ここに, $\omega_{n}$ : 固有円振動数, $h_{n}$ : 減衰定数.

式（1）で定義された地動加速度に対する相対変位 $y(t)$ および相対速度 $\dot{y}(t)$ の 分散 $\sigma_{y}{ }^{2}(t), \sigma_{\dot{y}}{ }^{2}(t)$ は, それぞれ次式のように表わされる。

$$
\begin{aligned}
\sigma_{y}{ }^{2}(t)= & E\left[y^{2}(t)\right]=\frac{1}{\bar{\omega}_{n}^{2}} \int_{0}^{t} h\left(t-t^{\prime}\right) d t^{\prime} \\
& \int_{0}^{t} h\left(t-t^{\prime \prime}\right) E\left[\ddot{z}\left(t^{\prime}\right) \ddot{z}\left(t^{\prime \prime}\right)\right] d t^{\prime \prime} \\
\sigma_{\dot{y}}{ }^{2}(t)= & E\left[\dot{y}^{2}(t)\right]=\frac{1}{\bar{\omega}_{n}^{2}} \int_{0}^{t} \dot{h}\left(t-t^{\prime}\right) d t^{\prime} \\
& \int_{0}^{t} \dot{h}\left(t-t^{\prime \prime}\right) E\left[\ddot{z}\left(t^{\prime}\right) \ddot{z}\left(t^{\prime \prime}\right)\right] d t^{\prime \prime}
\end{aligned}
$$

洞様に, $y(t)$ と $\dot{y}(t), y\left(t_{1}\right)$ と $y\left(t_{2}\right), y\left(t_{1}\right)$ と $\dot{y}\left(t_{2}\right)$ の相関係数 $\rho_{y \dot{y}}(t), \rho_{y y}\left(t_{1}, t_{2}\right), \rho_{y \dot{y}}\left(t_{1}, t_{2}\right)$ はそれぞれ 次式で表わされる。

$$
\begin{aligned}
& \rho_{y \dot{y}}(t)=E[y(t) \dot{y}(t)] /\left\{\sigma_{y}(t) \sigma_{\dot{y}}(t)\right\} \\
& =\frac{1}{\sigma_{y}(t) \sigma_{\dot{y}}(t) \bar{\omega}_{n}^{2}} \int_{0}^{t} h\left(t-t^{\prime}\right) d t^{\prime} \\
& \int_{0}^{t} \dot{h}\left(t-t^{\prime \prime}\right) E\left[\ddot{z}\left(t^{\prime}\right) \ddot{z}\left(t^{\prime \prime}\right)\right] d t^{\prime \prime} \\
& \rho_{y y}\left(t_{1}, t_{2}\right)=E\left[y\left(t_{1}\right) y\left(t_{2}\right)\right] /\left\{\sigma_{y}\left(t_{1}\right) \sigma_{y}\left(t_{2}\right)\right\} \\
& =\frac{1}{\sigma_{y}\left(t_{1}\right) \sigma_{y}\left(t_{2}\right) \bar{\omega}_{n}^{2}} \int_{0}^{t_{1}} h\left(t_{1}-t^{\prime}\right) d t^{\prime} \\
& \int_{0}^{t_{2}} h\left(t_{2}-t^{\prime \prime}\right) E\left[\ddot{z}\left(t^{\prime}\right) \ddot{z}\left(t^{\prime \prime}\right)\right] d t^{\prime \prime} \\
& \rho_{y \dot{y}}\left(t_{1}, t_{2}\right)=E\left[y\left(t_{1}\right) \dot{y}\left(t_{2}\right)\right] /\left\{\sigma_{y}\left(t_{1}\right) \sigma_{\dot{y}}\left(t_{2}\right)\right\} \\
& =\frac{1}{\sigma_{y}\left(t_{1}\right) \sigma_{\dot{y}}\left(t_{2}\right) \bar{\omega}_{n}^{2}} \int_{0}^{t_{1}} h\left(t_{1}-t^{\prime}\right) d t^{\prime} \\
& \int_{0}^{t_{2}} \dot{h}\left(t_{2}-t^{\prime \prime}\right) E\left[\ddot{z}\left(t^{\prime}\right) \ddot{z}\left(t^{\prime \prime}\right)\right] d t^{\prime \prime}
\end{aligned}
$$

また $g(t)$ のスペクトル密度 $S_{g}(\omega)$ を用いて

$$
E\left[\ddot{z}\left(t^{\prime}\right) \ddot{z}\left(t^{\prime \prime}\right)\right]=\beta^{2} f\left(t^{\prime} ; \tau\right) f\left(t^{\prime \prime} ; \tau\right)
$$

$$
\int_{0}^{\infty} S_{g}(\omega) \cos \omega\left(t^{\prime}-t^{\prime \prime}\right) d \omega
$$

と書けるから，式 (2),(5),(7),(10) を式 (8), (9) に 代入して $t^{\prime}, t^{\prime \prime}$ に関する積分を遂行すると，式 (8), (9) の右辺は $\omega$ に関する積分となる ${ }^{9), 10)}$ 。さらに, Caughey と Stumpf ${ }^{12)}$ と同様の方法によって $\omega$ に関する積分を 近似評価すると, 式 (8)，(9) の積分演算を完了するこ とができる。その結果はかなり複雑であるから，詳しく は文献 10),11) にゆずるが, $\sigma_{y}(t), \sigma_{\dot{y}}(t)$ については, さらに簡略化されてしかも十分な精度を有する次の近似 式が得られる ${ }^{11)}$ 。

$$
\left.\begin{array}{l}
\sigma_{y}{ }^{2}(t) \\
\sigma_{\dot{y}}{ }^{2}(t) / \omega_{n}^{2}
\end{array}\right\} \cong \frac{\pi \beta^{2} A^{2}}{4 \omega_{n}^{3}} S_{g}\left(\omega_{n}\right) e_{1}(t)
$$
ただし，

$$
\begin{aligned}
e_{1}(t)= & \frac{e_{0}(s, s, t)}{\lambda(s)}+\frac{e_{0}((1+\xi) s,(1+\xi) s, t)}{\lambda((1+\xi) s)} \\
& -\frac{2}{\lambda(s)+\lambda((1+\xi) s)}\left\{e_{0}(s,(1+\xi) s, t)\right.
\end{aligned}
$$
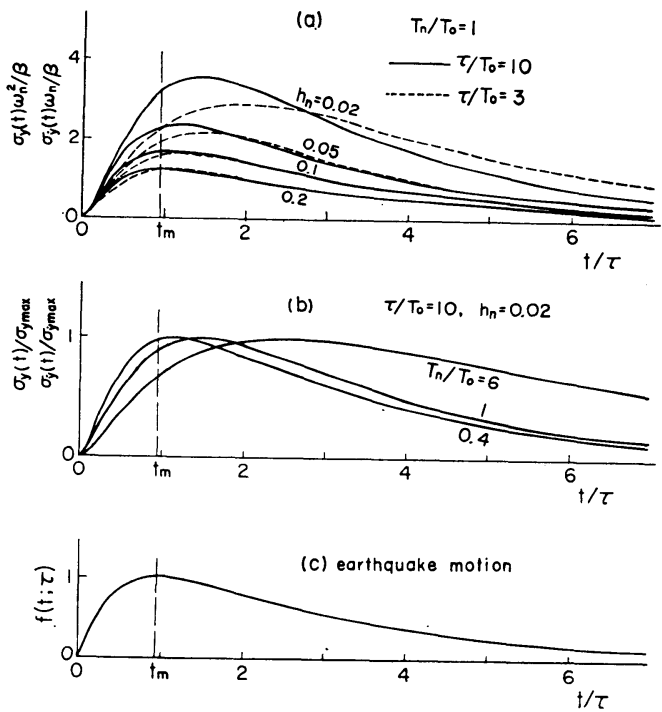

Fig. 3 r.m.s. Response (Standard Deviation) to Earthquake.
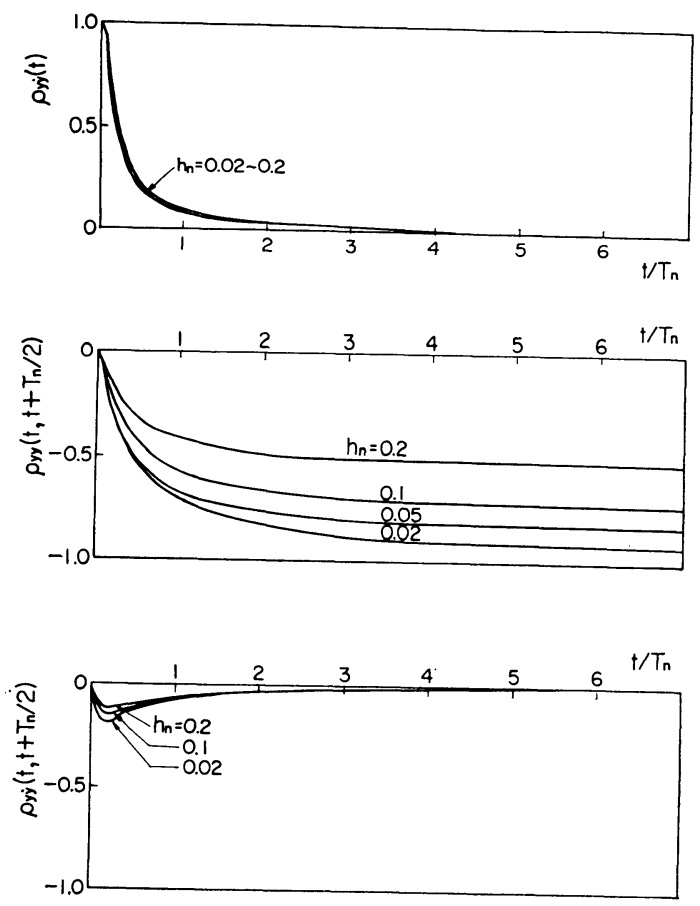

Fig. 4 Correlation Coefficients of Earthquake Response $\left(\tau / T_{0}=10, T_{n} / T_{0}=1\right)$. 


$$
\begin{gathered}
\left.+e_{0}((1+\xi) s, s, t)\right\} \\
e_{0}\left(s_{1}, s_{2}, t\right)=e^{-\left(s_{1}+s_{2}\right) t}-e^{-2 h_{n} \omega_{n} t} \\
A=(1+\xi)^{(1+1 / \xi)} / \xi, \lambda\left(s_{1}\right)=h_{n}-s_{1} / \omega_{n}
\end{gathered}
$$

このようにして算出された $\sigma_{y}(t), \sigma_{j}(t), \rho_{y} \dot{y}(t), \rho_{y} y$ $\left(t_{1}, t_{2}\right), \rho_{y \dot{y}}\left(t_{1}, t_{2}\right)$ の例を Fig. 3, 4 に示した。Fig. 3 において, $\sigma_{y}(t), \sigma_{\dot{y}}(t)$ が最大となる時刻は, 地震動 の強度 $f(t ; \tau)$ が最大となる時刻 $t_{m}$ より遅れて現われ ており，この傾向は， $\tau / T_{0}$ が小さいか $T_{n} / T_{0}\left(T_{n}\right.$ は 固有周期）が大きくて地震動が相対的に衝撃的なほど, また減衰定数 $h_{n}$ が小さくて初期条件の影響が長時間に 及ぶほど著しいことが注目される。この時間差の大小 は, 次節以降で述べる最大応答の確率分布の近似解法の 精度に影響を与える。さらに， $\sigma_{y}(t)$ の大きさを表わす 一つの尺度として, $\sigma_{y}(t)$ の最大值 $\sigma_{y \max }$ の例を Fig.

\section{5 に示した。}
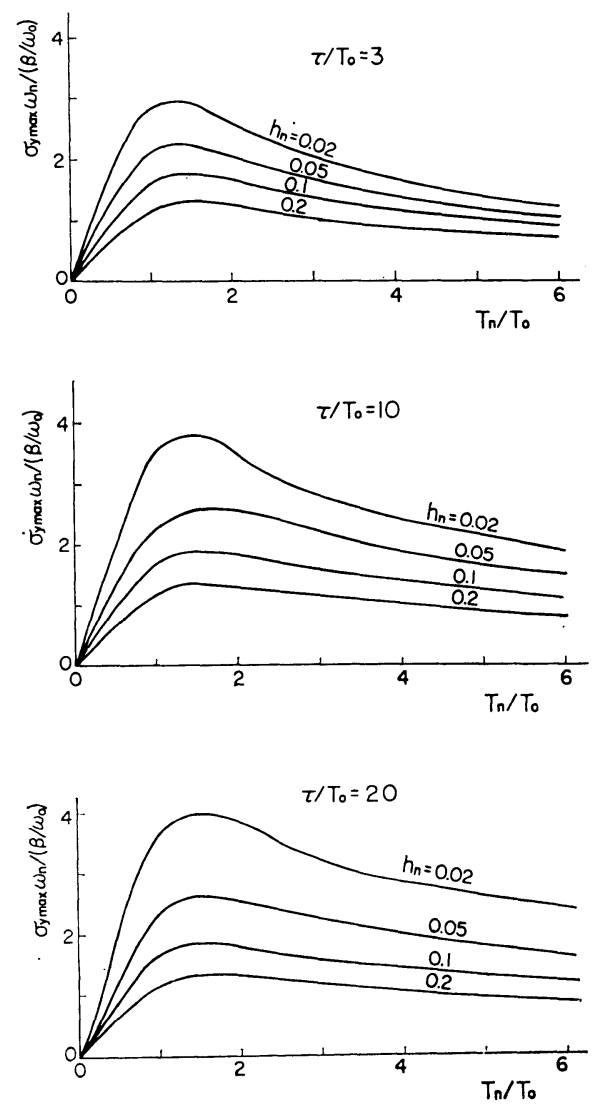

Fig. 5 Maximum r.m.s. Response.

\section{4. 最大応答の確率分布}

\section{（1）純出生過程による解法}

地震応答 $y(t)$ の絶対最大值を $Y$ とすると, $Y$ の確
率分布 $\Phi(Y)$ は次式のよらに表わすことができる。

$$
\Phi(Y)=P[\max |y(t)| \leqq Y ; 0 \leqq t<\infty]
$$

式 (12) は, 純出生過程の微分方程式の一つで表現さ れ，それを解くと次の形の解をらる ${ }^{7), 13)}$

$$
\Phi(Y)=a_{0}(Y) \exp \left\{-\int_{0}^{\infty} c_{0}(Y, t) d t\right\}
$$

ただし，

$$
\begin{aligned}
& a_{0}(Y)=P[|y(0)| \leqq Y] \\
& c_{0}(Y, t) d t \\
& =\frac{P\left[|y(t+d t)|>Y \cap \max \left|y\left(t^{\prime}\right)\right| \leqq Y ; 0 \leqq t^{\prime} \leqq t\right]}{P\left[\max \left|y\left(t^{\prime}\right)\right| \leqq Y ; 0 \leqq t^{\prime} \leqq t\right]}
\end{aligned}
$$

式 (13)の $\Phi(Y)$ は, 最大応答の確率分布の厳密解を 表わすが，同式右辺の $c_{0}(Y, t)$ を求めることが困難な ために，このままでは $\Phi(Y)$ を計算することができな い。そこで， $c_{0}(Y, t)$ を近似的に表わすことを試みる。 式 (14) は連続な $t^{\prime}$ について満足されねばならないが, いま

$$
0 \leqq t_{1}<t_{2}<\cdots<t_{r}<t
$$

なる $r$ 個の時刻についてのみ同式を満足するような確 率量 $\bar{c}_{0}(Y, t)$ を考える。すなわち

$$
\begin{gathered}
\bar{c}_{0}(Y, t) d t \\
=\frac{P\left[\{|y(t+d t)|>Y \cap|y(t)| \leqq Y\} \cap\left\{\bigcap_{k=1}^{r}\left|y\left(t_{k}\right)\right| \leqq Y\right\}\right]}{P\left[|y(t)| \leqq Y \cap\left\{\bigcap_{k=1}^{r}\left|y\left(t_{k}\right)\right| \leqq Y\right\}\right]} \\
=\frac{Q_{1}(Y, t)}{Q_{2}(Y, t)} d t \ldots \ldots \ldots \ldots \cdots \cdots \cdots(15)
\end{gathered}
$$

ただし，

$$
\begin{aligned}
& Q_{1}(Y, t) d t= P[\{|y(t+d t)|>Y \cap|y(t)| \leqq Y\} \\
&\left.\cap\left\{\bigcap_{k=1}^{r}\left|y\left(t_{k}\right)\right| \leqq Y\right\}\right] \\
& Q_{2}(Y, t)=P\left[|y(t)| \leqq Y \cap\left\{\bigcap_{k=1}^{r}\left|y\left(t_{k}\right)\right| \leqq Y\right\}\right]
\end{aligned}
$$

かかる $\bar{c}_{0}(Y, t)$ を $c_{0}(Y, t)$ の近似的表現として用いる と, 式 (12) の近似式として次式をうる。

$$
\Phi(Y) \cong a_{0}(Y) \exp \left\{-\int_{0}^{\infty} \bar{c}_{0}(Y, t) d t\right\}
$$

式 (15) の $Q_{1}(Y, t), Q_{2}(Y, t)$ は次式のように表わ される ${ }^{11), 13) 。}$

$$
\begin{aligned}
& Q_{1}(Y, t)=\frac{\sigma_{v}}{\sigma_{t}} \int_{-Y / \sigma_{1}}^{Y / \sigma_{1}} d \xi_{1} \int_{-Y / \sigma_{2}}^{Y / \sigma_{2}} d \xi_{2} \cdots \\
& \quad \int_{-Y / \sigma_{r}}^{Y / \sigma_{r}}\left\{\int_{-\infty}^{0}\left|\dot{\xi}_{t}\right| \phi_{1 n}\left(\xi_{1}, \xi_{2}, \cdots, \xi_{r},-\frac{Y}{\sigma_{t}}, \dot{\xi}_{t}\right) d \xi_{t}\right. \\
& \left.\quad+\int_{0}^{\infty} \xi_{t} \phi_{1 n}\left(\xi_{1}, \xi_{2}, \cdots, \xi_{r}, \frac{Y}{\sigma_{t}}, \xi_{t}\right) d \xi_{t}\right\} d \xi_{r}
\end{aligned}
$$

$$
Q_{2}(Y, t)=\int_{-Y / \sigma_{1}}^{Y / \sigma_{1}} d \xi_{1} \int_{-Y / \sigma_{2}}^{Y / \sigma_{2}} d \xi_{2} \cdots \int_{-Y / \sigma_{r}}^{Y / \sigma_{r}} d \xi_{r}
$$




$$
\int_{-Y / \sigma_{t}}^{Y / \sigma_{t}} \phi_{2 n}\left(\xi_{1}, \xi_{2}, \cdots, \xi_{r}, \xi_{t}\right) d \xi_{t}
$$

ただし，

$$
\begin{aligned}
& \xi_{i}=y\left(t_{i}\right) / \sigma_{i}, \sigma_{i}=\sigma\left(t_{i}\right) ; i=1,2, \cdots, r \\
& \xi_{t}=y(t) / \sigma_{t}, \dot{\xi}_{t}=\dot{y}(t) / \sigma_{v}, \sigma_{t}=\sigma_{y}(t), \sigma_{v}=\sigma_{\dot{y}}(t)
\end{aligned}
$$

また $\phi_{1 n}\left(\xi_{1}, \xi_{2}, \cdots, \xi_{r}, \xi_{t}, \xi_{t}\right), \phi_{2 n}\left(\xi_{1}, \xi_{2}, \cdots, \xi_{r}, \xi_{t}\right)$ は, それぞれの変数の確率密度関数である。

式 (17), (18) 右辺の確率密度関数 $\phi_{1 n}, \phi_{2 n}$ の形は任 意であるが，2. で設定した地震動 $\ddot{z}(t)$ の振幅分布を 正規分布としたこと，および線形構造物では入力が正規 過程であれば応答もまた正規過程となることを考慮すれ ば, $\phi_{1 n}, \phi_{2 n}$ についても多次元正規分布の場合が特に重 要である。正規分布の場合には, 式 (17),(18) 右辺の 積分の回数を 1 回減ずることができ ${ }^{11), 13)}, r=0,1$ の場 合にはさらに簡略化できる ${ }^{13)}$ 。

以上の解法は，近似的であるが，相異なる時刻での応 答間の相関の影響を取り入れたもので, 考慮する時刻の 数 $r$ を増すほど精度が向上する ${ }^{13), 14)}$ 。以下， $r=0$ の 場合を第一近似， $r=1$ を第二近似と順次呼ぶことにす る。応答 $y(t)$ が過去の応答経歴から独立であるとする 従来の研究 ${ }^{4), 5), 6)}$ は, $r=0$ なる第一近似として本解法に 含まれる。

前節 3. で求めた応答の分散および相関係数を本節の 近似解法に用いて, 最大応答の確率分布を求めた。本報 告では $r=1$ なる第二近似を採用し， $t_{1}$ としては比較的
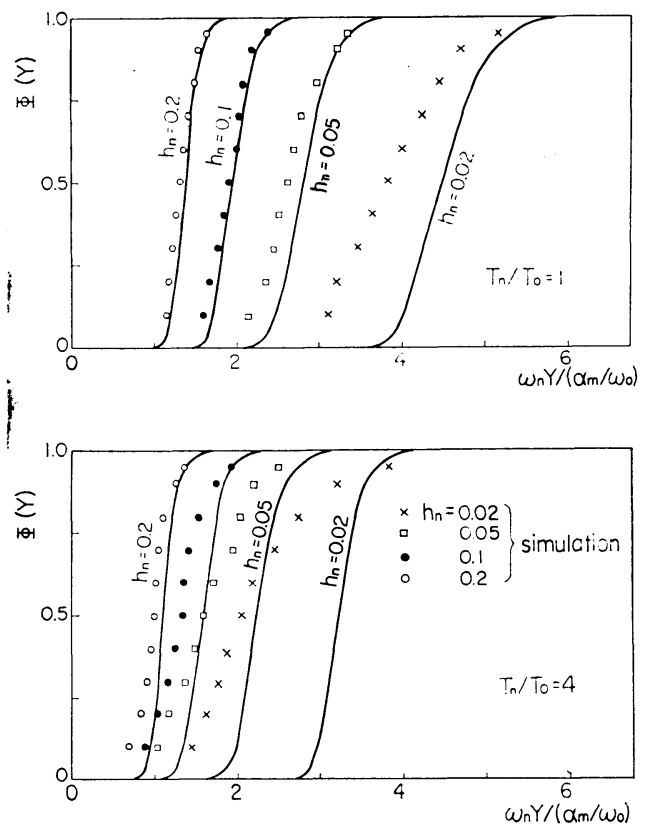

Fig. 6 Probability Distribution of the Maximum Earthquake Response Based on the Pure. Birth-Process Method $\left(\tau / T_{0}=3\right)$.
精度が良い ${ }^{13)} t_{1}=t-T_{n} / 2$ を用いた。同時に, 電子計算 機内のシミェレーションによって発生させた地震波に対 する最大応答を運動方程式の数值積分によって求め, そ の累積頻度分布から最大応答の確率分布の数值実験值を 算出して，これを用いて理論值の精度を検討した。標本 数は各場合につき 40 である。計算結果の一部を Fig. 6〜8 に示した。シミュレーションの結果が厳密解に近
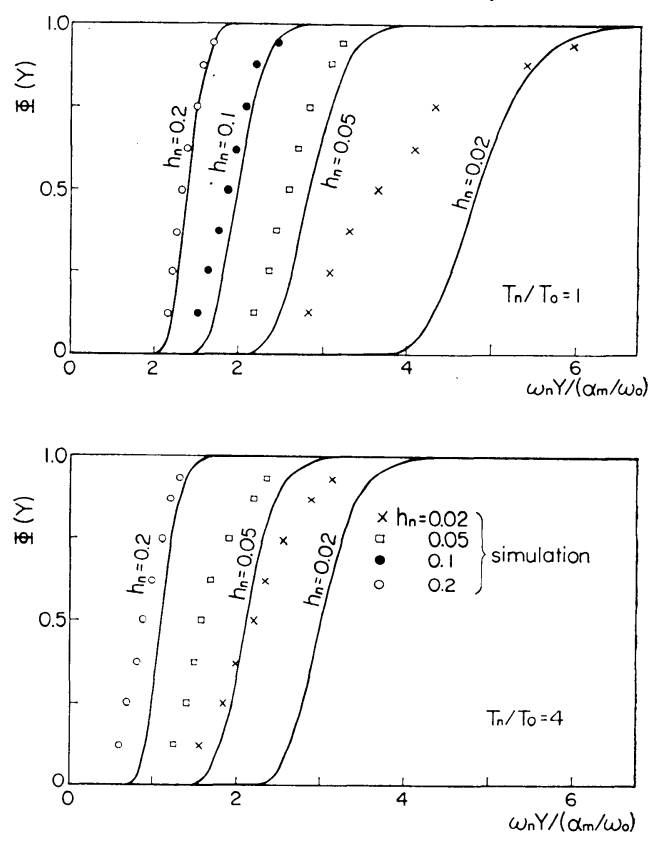

Fig. 7 Continued $\left(\tau / T_{0}=10\right)$.
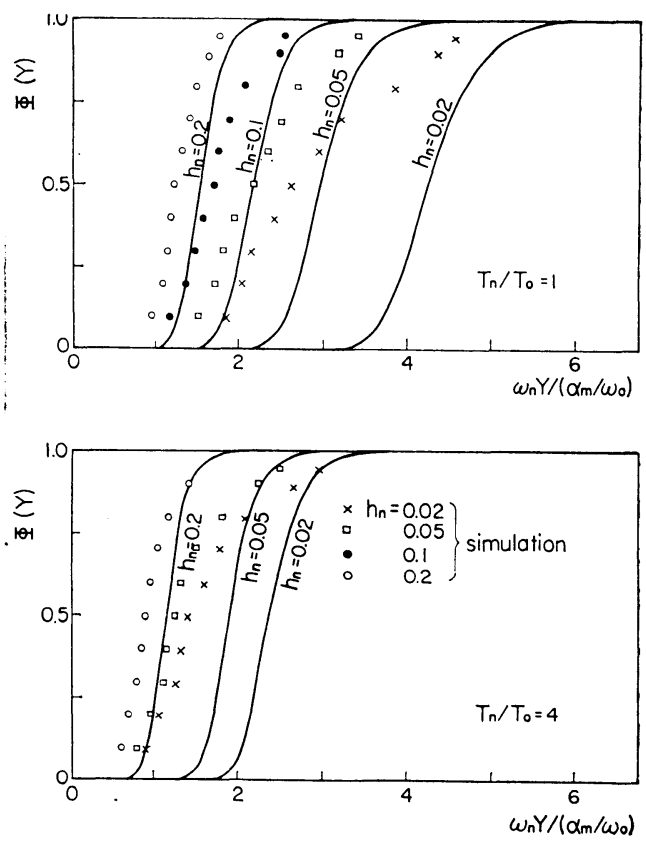

Fig. 8 Continued $\left(\tau / T_{0}=20\right)$. 


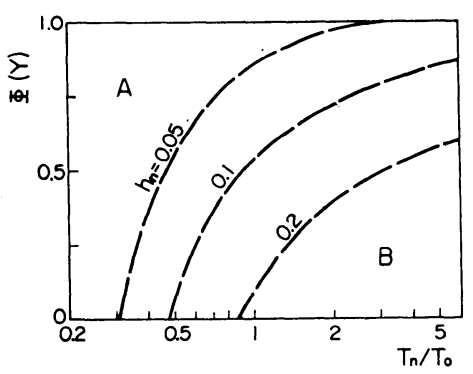

(a) $\tau / T_{0}=3$

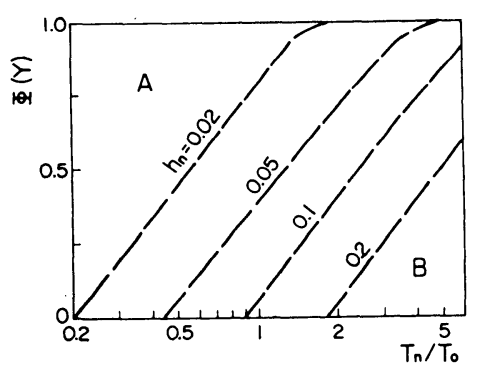

(b) $\tau / T_{0}=10$

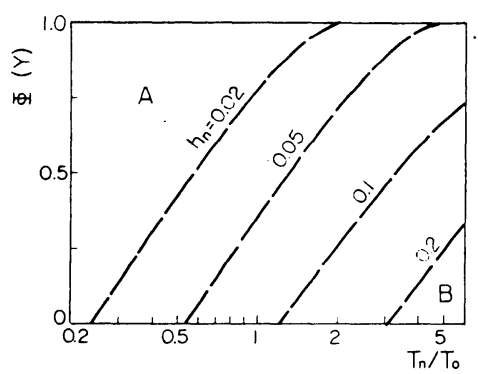

(c) $\tau / T_{0}=20$

Fig. 9 Precision Zoning for the Pure-Birth-Process Method.

いものと考えると, これらの計算結果から, 純出生過程 による近似解は， $T_{n} / T_{0}$ が大きいほど，また $\tau / T_{0}$ と $h_{n}$ が小さいほど精度が低下寸ることがわかる。その原 因としては次のような事項が考えられる。i） $h_{n}$ が小さ くなると,かなり隔った時刻（たとえば $T_{n}$ の数倍）の 間でも応答間に比較的高い相関があり，本節の近似解法 でも十分な精度を期待できない。ii） $\tau / T_{0}$ が小さいか， $T_{n} / T_{0}$ が大きくなると,地震動が構造物に対して衝撃的 に作用することになり，Fig. 3 において $\sigma_{y}(t)$ が最大 值 $\sigma_{y \max }$ となる時刻には, 外力強度を表わす $f(t ; \tau)$ は すでにかなり減少していることから，それ以後の応答に は, 減衰自由振動の影響が強いと考えられる。したがっ て, この部分も最大応答值に貢献すると考える本解法で は，最大応答を過大に推定する結果となる。

以上の結果において, たとえば Fig. 7 の $\tau / T_{0}=10$, $T_{n} / T_{0}=1, h_{n}=0.05$ の場合を 許容しうる誤差の限度と すれば, 純出生過程による解法を適用しらる範囲は大略 Fig. 9 のA 領 域で示される。たとえば, Fig. 9 (b) において, $h_{n}=0.1, T_{n} / T_{0}=2$ であれば, この解法は $\Phi(Y)>0.4$ の範囲で適用可能である。ただし, Fig. 9 はあくまで精度の一つの目安を示すもので, 実際の精度 は同図の曲線の両側で連続的に変化していることはいう までもない。

\section{（2）応答包絡線の極值による解法}

純出生過程による近似解法の精度が低下するパラメー タ一領域では, 他の方法によって最大応答の確率分布を 求めることが必要となるが, 精度低下の原因として前述 した事項のうち, $T_{n} / T_{0}$ が大きいか $\tau / T_{0}$ が小さくて, 構造物に対して地震動が相対的に衝撃的である場合に は, $\sigma_{y}(t)$ が最大值 $\sigma_{y \max }$ をとる時刻前後の応答のみ が最大応答に関与し, それ以後の応答は主として自由振 動によるものとして無視できるような解法が望ましい。 ここではそのために, 忘答包絡線の極值分布に関する理 論を応用する。

不規則外力に対する構造物の応答は, 多くの場合固有

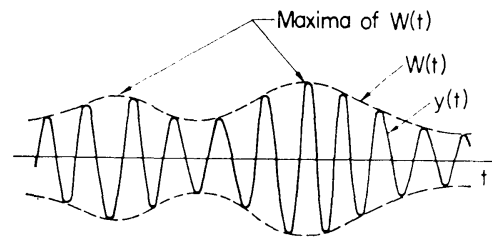

Fig. 10 Illustration of Amplitude $y(t)$, Envelope $W(t)$ and Peak Envelope (Maxima of $W(t)$ ).

周期に近い周期で振動する狭帯域の確率過程 で表わさ れ, Fig. 10 のように, 振動周期に比較してゆるやかに 変動する包絡線 $W(t)$ を持つが, $W(t)$ の極值*は, そ れが発生した時刻前後での応答 $y(t)$ の絶対最大值とみ なしてよい。前述のように, 応答の r.m.s. 強度 $\sigma_{y}(t)$ が 最大となる比較的短い時間領域で発生するような最大応 答を論ずるのがここでの目的であるから， $\sigma_{y}(t)=\sigma_{y \text { max }}$ となる時刻の近傍における $W(t)$ の極大值が地震動に 対する最大応答を表わすものと考える。

狭帯域の確率過程における包絡線の極值の分布はすで に Rice ${ }^{15)}$ によって取り扱われ，正規定常過程に対する 解が与えられている。本研究では構造物の応答は非定常 過程であるが，ここで問題にしているような $\sigma_{y}(t)$ が最 大值をとる時刻前後では， $\sigma_{y}(t)$ はきわめてゆるやかに 変化し， $\rho_{y \dot{y}}(t)$ は 0 亿近い值となるから，y(t) はほぼ 定常過程とみなしてよいと考えられる。このような論拠 により, 包絡線の極值分布に関する Rice の結果を構造 物の応答に適用解析した結果, 最大応答の確率密度関数 $\phi(Y)$ として次式が得られた。

$$
\phi(Y) \cong \phi_{E}(Y)=p(Y) / \int_{0}^{\infty} p(Y) d Y
$$

ただし，

$$
p(Y)=\frac{1}{4 \sigma_{y m}}\left\{\frac{32 a^{5} Z^{3}}{a^{2}-1}\left(\frac{Y}{\sigma_{y m}}\right)^{3}\right\}^{1 / 2} \exp
$$

* 本論文冒頭脚注の 講演発表では $W(t)$ の極值を peak envelope と称したが， $y(t)$ の極值と混用されやすいので, 本論文においては，この表現は図面の説明にのみ用い，本 文中では応答包絡線の極值と呼ぶことにする。 


$$
\left\{-a^{2} Z^{2}\left(\frac{Y}{\sigma_{y m}}\right)^{2}\right\} \sum_{n=0}^{\infty} \frac{Z^{n} A_{n}}{\Gamma\left(\frac{n}{2}+\frac{7}{4}\right)}\left(\frac{Y}{\sigma_{y m}}\right)^{n}
$$

$$
\begin{aligned}
A_{n}= & \left\{\begin{array}{l}
1 ; n=0 \\
n+1+\sum_{m=1}^{n} \frac{\left(\frac{1}{2}\right)\left(\frac{3}{2}\right) \cdots\left(m-\frac{1}{2}\right)}{m !}(n-m+1) b^{m} ;
\end{array}\right. \\
b= & \frac{1}{2}\left(3-a^{2}\right), \quad a=\frac{\sqrt{b_{4}}}{b_{2}} \sigma_{y m}, Z=\frac{b_{2}}{\sqrt{2\left(\sigma_{\left.y m^{2} b_{4}-b_{2}{ }^{2}\right)}\right.}} \\
& b_{k}=\int_{0}^{\infty}\left(\omega-\omega_{n}\right)^{k} S_{y}(\omega) d \omega ; k=2,4
\end{aligned}
$$

$\Gamma(x)$ はガンマ関数である。

これらの結果から, 最大応答の確率分布は次式で与え られる。

$$
\Phi(Y) \cong \Phi_{E}(Y)=\int_{0}^{Y} \phi_{E}(Y) d Y
$$

式 (20) の $\sigma_{y m}$ は，応答レベルが最大となる時刻前 後における r.m.s. 応答 $\sigma_{y}(t)$ の代表值であり, 後述の 数值計算結果 (Fig. 12１4）に掠いてYの大きい領域 で理論解とシミュレーションの結果とを一致させるとい ら基準を用いた結果, Fig. 11 によって $\sigma_{y \max }$ から換 算すればよいことがわかった。をた，式（20）の計算に 必要な $S_{y}(\omega)$ は, 応答 $y(t)$ のスペクトル密度に一致 すべきものであるが, 式 (19),(20) は, 固有振動数 $\omega_{n}$ に関して対称なスペクトル密度に関してのみ成り立つ15) から， $S_{y}(\omega)$ の近似的表現として次式を用いる。

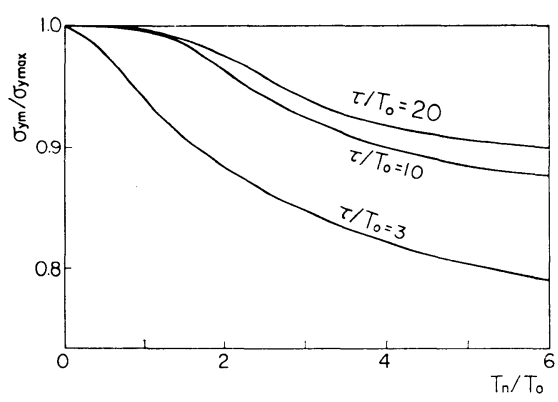

Fig. 11 Reduction Factor to Determine $\sigma_{y m}$.

$$
\begin{aligned}
S_{y}(\omega) \equiv \equiv & \bar{S}_{y}(\omega)=\frac{\sigma_{y m^{2}}}{\pi h_{n} \omega_{n}} \\
& \cdot \exp \left\{-\left(\frac{\Gamma(1 / 4)}{2 \pi h_{n}}\right)^{4}\left(\frac{\omega}{\omega_{n}}-1\right)^{4}\right\}
\end{aligned}
$$

式 (22) の $\bar{S}_{y}(\omega)$ は, $\omega=\omega_{n}$ の近傍で $S_{y}(\omega)$ と同 様に 4 次曲線的に変化すること, 式 (22) から求められ る応答分散值が $\sigma_{y m}{ }^{2}$ に一致すること, ピークの高さが

$$
\bar{S}_{y}\left(\omega_{n}\right)=S_{y}\left(\omega_{n}\right)=\sigma_{y m}{ }^{2} /\left(\pi h_{n} \omega_{n}\right)
$$

となることを条件として定めたものである。式（22）の $S_{y}(\omega)$ を用いることにより，式（20）の諸定数は次式
のように求められる。

$$
\begin{aligned}
& b_{2}=\frac{\sigma_{y m^{2}} \gamma^{3} \omega_{n}^{2}}{2 \pi h_{n}} \Gamma\left(\frac{3}{4}\right), b_{4}=\frac{\sigma_{y m^{2}} \gamma^{5} \omega_{n}^{4}}{2 \pi h_{n}} \Gamma\left(\frac{5}{4}\right), \\
& r=2 \pi h_{n} / \Gamma\left(\frac{1}{4}\right) \\
& Z=0.43195, a^{2}=2.1884, \quad b=0.40578
\end{aligned}
$$
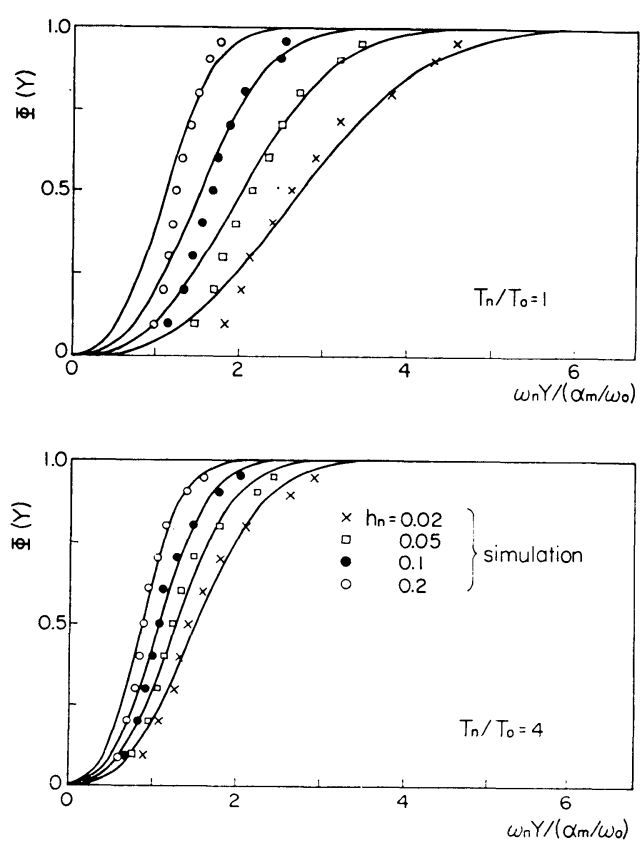

Fig. 12 Probability Distribution of the Maximum Earthquake Response Based on the Peak Envelope Method $\left(\tau / T_{0}=3\right)$.
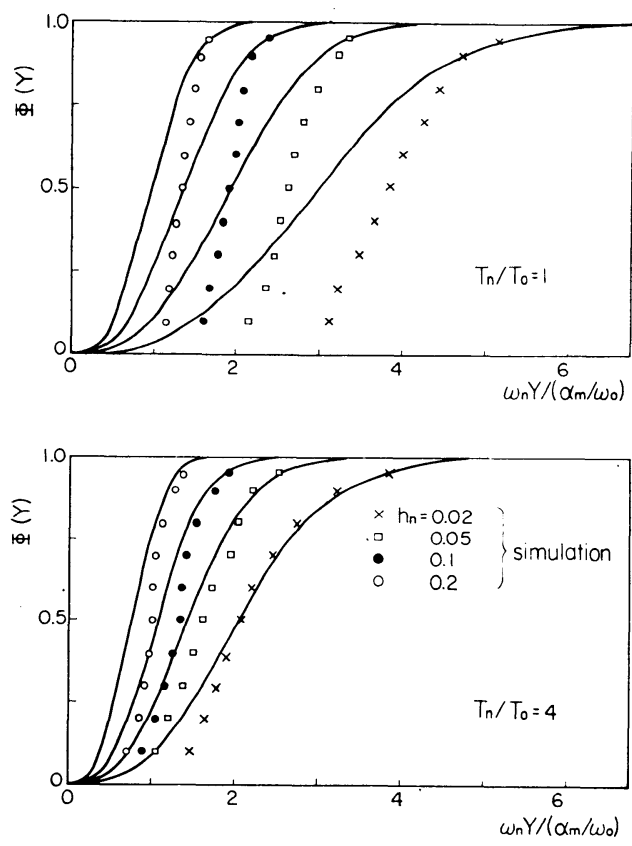

Fig. 13 Continued $\left(\tau / T_{0}=10\right)$. 

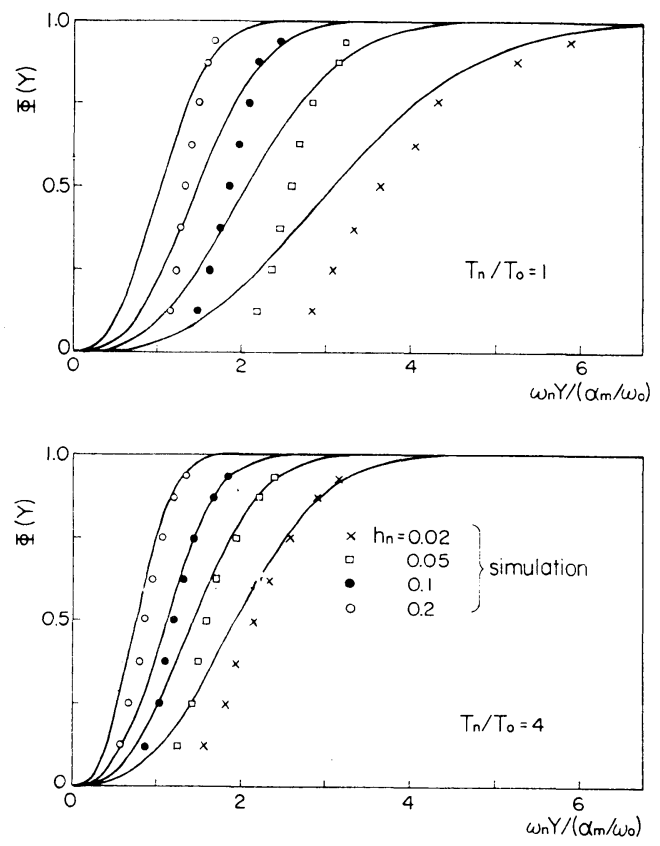

Fig. 14 Continued $\left(\tau / T_{0}=20\right)$.

以上のようにして応答包絡線の極值の理論から最大応 答の確率分布の近似解が求められたが, 式 (21) に対す る数值計算結果の一部を, シミュレーションの結果とと もに Fig. 12 14 に示した。また, Fig. 9 と同様にし て応答包絡線の極值による解法の適用範囲を示したのが

Fig.15のA 領域である。Fig. 6〜8 と Fig. 12〜14, または Fig. 9 と Fig. 15 を比較すると, 純出生過程 による解法の精度が低下する範囲では応答包絡線の極值 による解法の精度が良く, 逆に純出生過程による解法の 精度が良い範囲, すなわち応答 $y(t)$ が全継続時間にわ たってランダムな性質を有する場合には，応答包絡線の 極值による解法の精度が悪化することがわかる。すなわ ち, 比較的短周期の構造物に定常的な地震動が作用する 場合ほど純出生過程による解法, 比較的長周期の構造物 に衝撃的な地震動が作用する場合ほど応答包絡線の極値 による解法が優れているといえる。

\section{5. 最大地震応答の推定法について}

前節で論じた最大応答の確率分布 $\Phi(Y)$ は, 不規則 地震動に対する構造物の最大応答について, 最も一般的 な確率統計的情報を与えるものであり，これに基づい て, 実際の耐震設計に関連する種々の確率量を導くこと ができる。1.で述べたように, 最大応答の確率分布は, それ自体が構造物の非破壞確率に密接に関連した重要な 確率量であるが，最大地震応答の特性を包括的に把握 し, その結柴を耐震設計に結びっけて行くためには, こ れらの結果をより簡潔な図表で表示して, 考察を容易に するのが望ましいと考えられる。本節では，このような 目的のため, $\Phi(Y)$ から求められる二, 三の確率量から 最大地震応答の確率統計的性質を考察し, その推定法を 論ずる。

\section{（1）平均応答スペクトル}

最大地震応答の期待值 $E[Y]$ に対して

$$
S_{D}=E[Y], S_{V}=\omega_{n} S_{D}, S_{A}=\omega_{n}^{2} S_{D}
$$

とおき, $S_{D}, S_{V}, S_{A}$ と固有周期 $T_{n}$ との関係を図示し た結果は, 実地震波に対する応答解析の分野で発達して きた平均忘答スペクトルに対応するもので, それぞれ変 位応答スペクトル, 速度応答スペクトル, 加速度応答ス ペクトルを表わす。

前節の解法のうち, 純出生過程による解法から $E[Y]$ を求めるためには，次式を用いればよい?。

$$
E[Y]=\int_{0}^{\infty}\{1-\Phi(Y)\} d Y
$$

また, 応答包絡線の極值による解法からは次の結果が得 られた。

$$
E[Y] \cong \int_{0}^{\infty} Y \phi_{E}(Y) d Y=2.5038 \sigma_{y m}
$$

このようにして得られた平均応答スペクトルをシミュ レーションの結果とともに無次元表示したのが Fig.

16, 17 で, Fig. 16 は純出生過程による解法, Fig. 17 は応答包絡線の極值による解法の結果である。両図を比

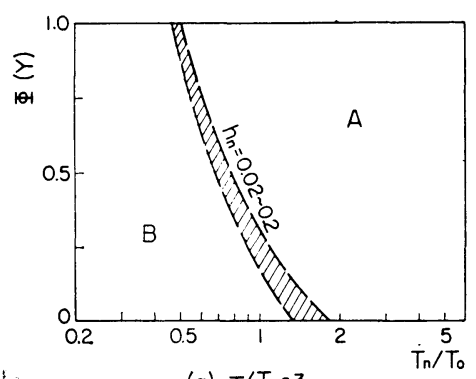

(a) $\tau / T_{0}=3$

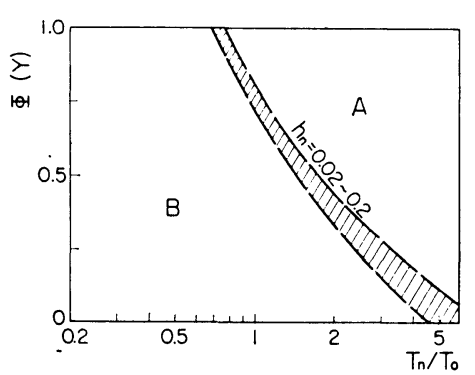

(b) $\tau / T_{0}=10$

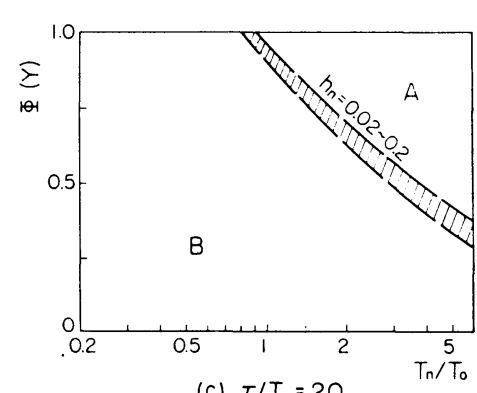

(c) $\tau / T_{0}=20$

Fig. 15 Precision Zoning for the Peak Envelope Method. 
較すると，これら二種の解法の精度は，当然のことなが ら, 前節で論じたのと同様の傾向で変化することがわか る。

次に Fig. 16,17 において, 地震動の継続時間 $\tau$ の
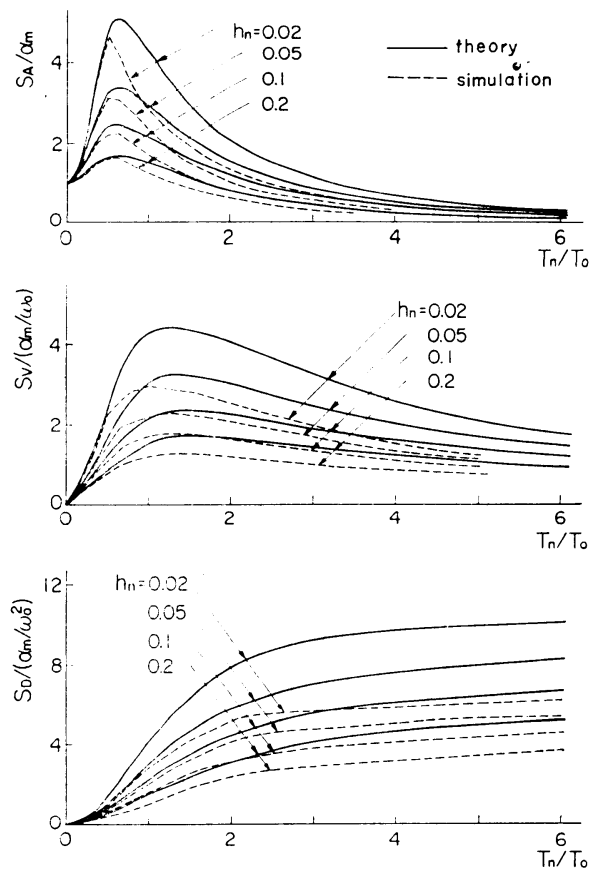

(a) $\tau / T_{0}=3$
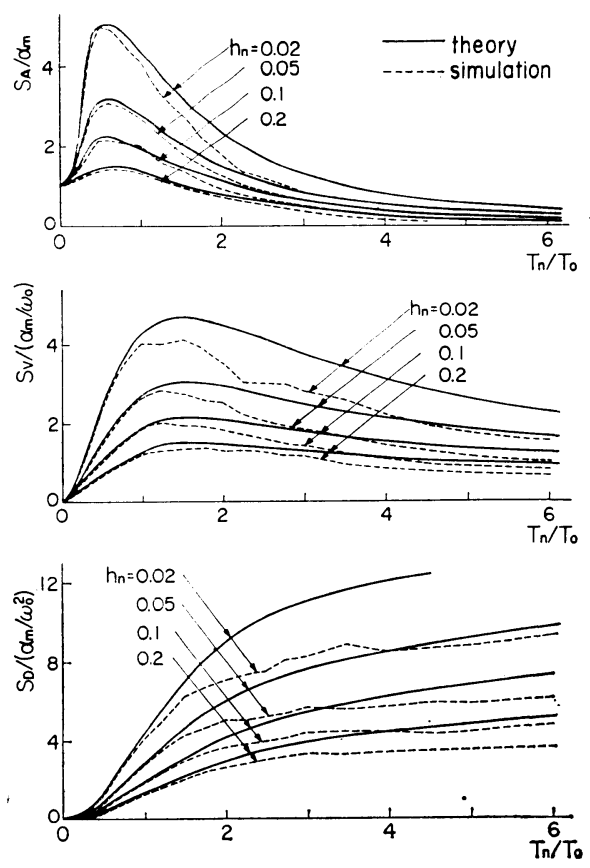

(b) $\tau / T_{0}=10$
増大とともに平均最大応答が増加している。この傾向は 全体としてはあまり著しくないが，たとえば $h_{n}=0.02$ の場合で $T_{n} / T_{0}>1$ なる 長周期構造物に $\tau / T_{0}=3$ 程度 の地震動が作用した場合には，明らかに $\tau / T_{0}=10,20$ の場合より低い忘答值となっている。このことは, 衝撃 的な地震動が長周期構造物に作用しても，応答が十分に 大きくなる前に地震動が終息することを意味しており， これは実地震に対する応答解析の結果とも一致する ${ }^{16)}$ 。 また, 減衰定数 $h_{n}$ との関係については, $h_{n}$ が小さい ほど初期条件による拘束が長時間におよぶ $\left.{ }^{14}\right)$ 結果, 継続 時間の影響を受けやすいものと考えられる。

さらに Fig. 16,17 で，特定の固有周期 $T_{n}$ に対す る平均最大応答は, 当然地震動の卓越周期 $T_{0}$ の影響を 受ける。最近, 栗林・岩崎・辻 ${ }^{17)}$ にり, 平均応答スペ クトルを地盤種別によって分類する試みが行なわれてい るが, 地盤条件と $T_{0}$ の間に密接な関係があるとされて いることをあわせ考えれば，この分野でのデータの集積 の必要性を本節の結果からも確認できるであろう。

\section{（2）最大応答の变動係数}

平均応答スペクトルは動的設計にしばしば用いられ， 将来の地震観測結果の集積とともに上記（1）で論じた よらな諸特性が明らかになるにしたがってその有用性は さらに増大するであろらが, 構造物の耐震安全性を明確
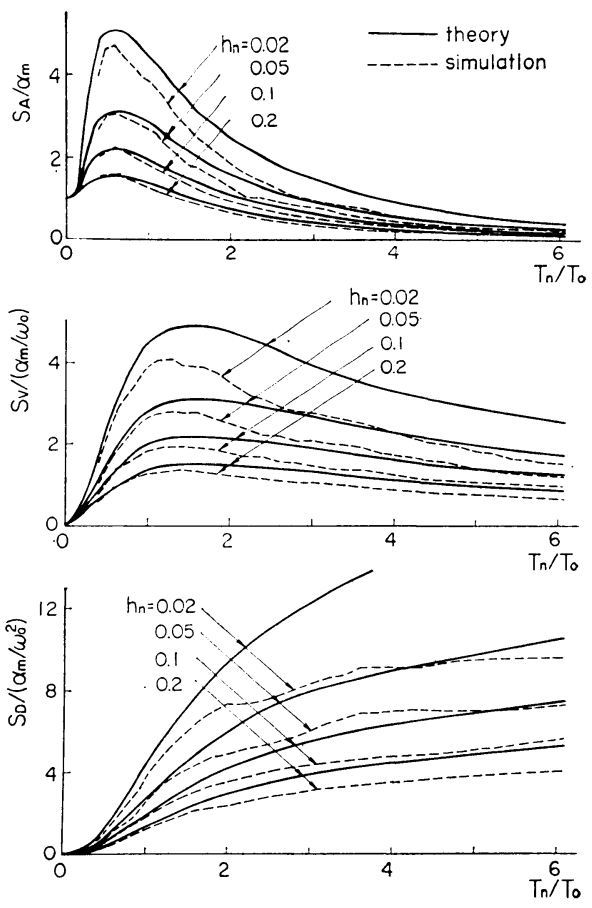

(c) $\tau / T_{0}=20$

Fig. 16 Mean Response Spectra Based on the Pure-Birth-Process Method. 
にするためには, 最大応答の平均值のみでなく, そのば らつきをも考慮に入れた議論が必要である。ここでは, 次式で与えられる最大応答の変動係数 $C_{v}$ を用いてこの 問題を論ずる。すなわち，
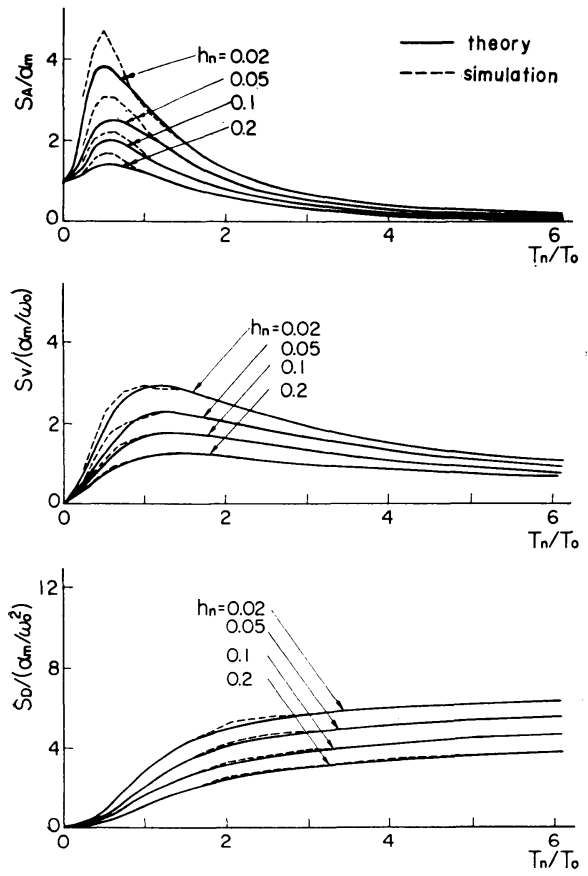

(a) $\tau / T_{0}=3$
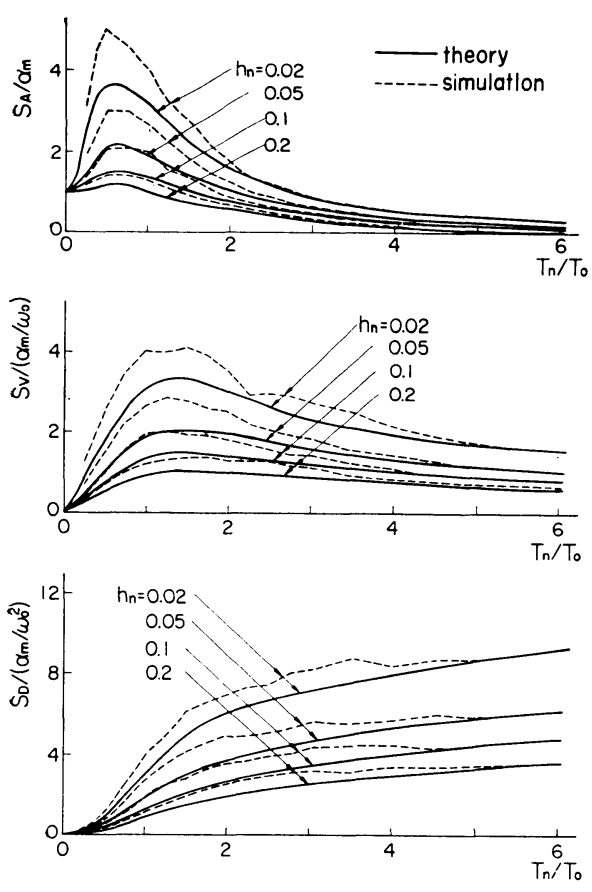

(b) $\tau / T_{0}=10$

$$
C_{v}=\sigma_{Y} / E[Y]=\left\{E\left[Y^{2}\right]-(E[Y])^{2}\right\}^{1 / 2} / E[Y]
$$

ただし， $\sigma_{Y}$ は最大応答の標準偏差である。

式（26）中の自乗平均 $E\left[Y^{2}\right]$ は, 純出生過程による 解法を用いるときは,

$$
E\left[Y^{2}\right]=2 \int_{0}^{\infty} d Y \int_{Y}^{\infty}\left\{1-\Phi\left(Y^{\prime}\right)\right\} d Y^{\prime}
$$

から算出すればよく ${ }^{11)}$ ，一方応答包絡線の極值による解 法を用いる場合には，次式から求められる。

$$
E\left[Y^{2}\right] \cong \int_{0}^{\infty} Y^{2} \phi_{E}(Y) d Y=7.3269 \sigma_{y m^{2}}
$$

$C_{v}$ の数值計算結果とシミュレーションの結果を Fig. 18 に示した。同図からわかるように, 純出生過程による 解法 (p.b.p.m.) では $C_{v}$ の值は $0.1 \sim 0.15$ 程度, 応 答包絡線の極值による解法 (p.e.m.) では $C_{v}=0.41083$ の定数となる。シミュレーションの結果はほぼこれら二 種の值の間で変化しているが, 近似解法の精度に関する これまでの議論と同様に， $T_{n} / T_{0}$ が小さいか $\tau / T_{0}$ が大 きいほど純出生過程による結果に近く, 逆の場合には応 答包絡線の極値による結果に近い值を示している。

これらの計算結果は, 平均応答スペクトルを耐震設計 に用いる場合，その安全性の評価を一律に行なえないこ とを示している。構造物の耐震安全性は, 終局性状を含 めた多くの要素から総合的に評価されるものであるが, いま問題を単純化して，最大応答のみでその評価を行な
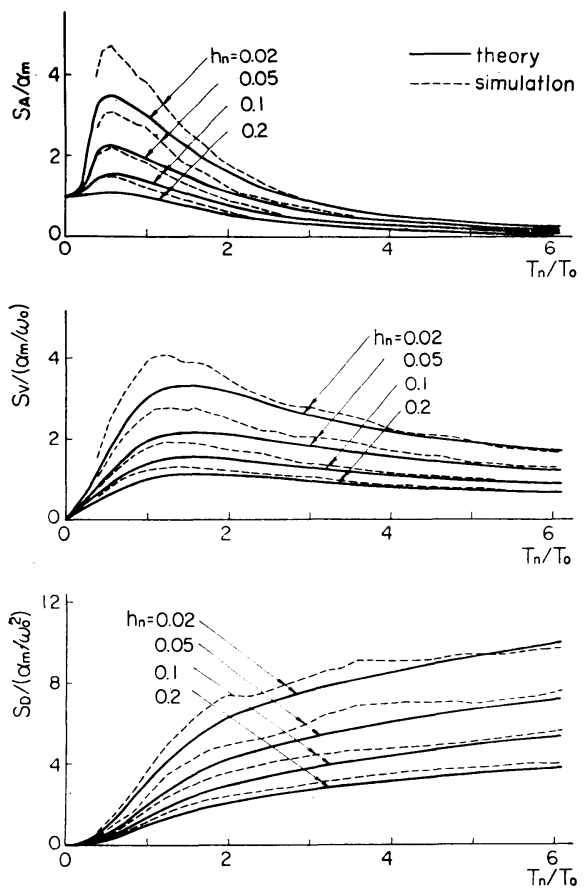

(c) $\tau / T_{0}=20$

Fig. 17 Mean Response Spectra Based on the Peak Envelope Method. 


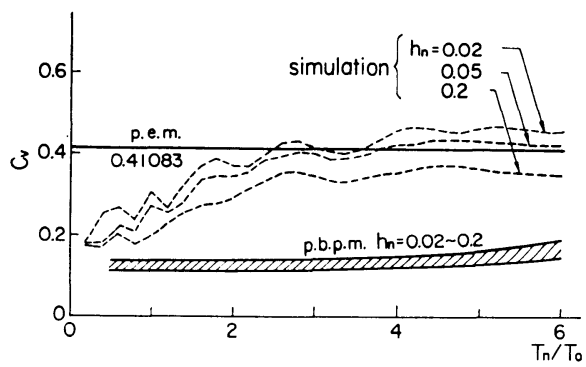

(a) $\tau / T_{0}=3$

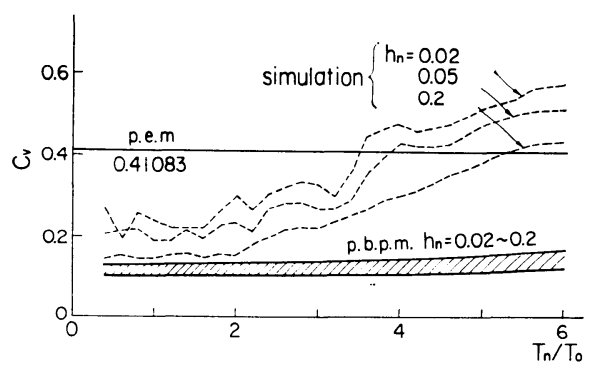

(b) $\tau / T_{0}=10$

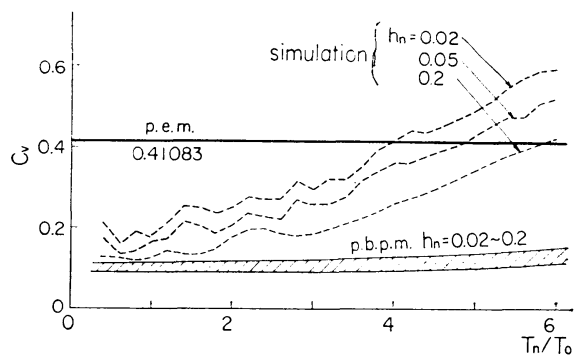

(c) $\tau / T_{0}=20$

Fig. 18 Relative Dispersion Spectra of the Maximum Response (p.b.p.m. : pure-birth-process method, p.e.m. : peak envelope method).

らものと考えると, 平均応答スペクトルを用いて耐震設 計を行なったとしても, その結果得られる構造物の非破 壊確率は, 固有周期によって, また地震動の継続時間に よって変化することになる。

以上の議論に関して，固有周期の影響については片 $山^{18)}$ が実地震記録の応答スペクトルから Fig. 18 と同 様の傾向を結論として導いている。これに加えて本節の 結果は, この問題を不規則振動論の側面から一般化し, 理論的根拠を示すものと考えられる。

\section{（3）一定の非超過（非破壊）確率に対する最大応答}

構造物の耐震設計において, 最大応答が一定の許容值 を越えない確率 (非超過確率) を非破壊確率と考え，こ れを安全性の基準として採用する場合, 要求される非超 過確率に対して最大応答の許容值が決定され, 設計計算

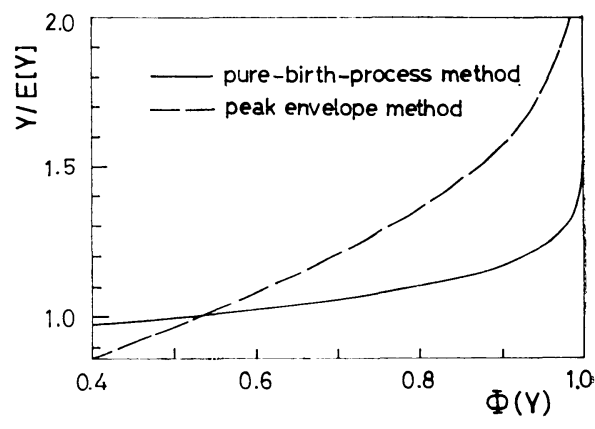

Fig. 19 Maximum Response Relative to Its Mean Value vs. the Non-Excess Probability.

が行なわれることになる。その際，許容最大応答值は， 平均応答スペクトルにある係数を掛けて求めるようにし ておくのが 便利であるが，上記（2）の所論から，少な くとも線形構造物に関しては, この倸数は構造物の固有 周期により，また地震動の継続時間によって変化する。 その典型的な場合として, 前節 4. の二つの近似解法か ら得られた結果を示したのが Fig. 19 である。純出生 過程による解法の結果は $h_{n}=0.05, T_{n} / T_{0}=1, \tau / T_{0}=$ 10 に対するものであるが，最大応答とその平均值の比 $Y / E[Y]$ を論ずる限りは，他の場合についてもほとんど 同様の結果が得られた。同図からわかるように，たとえ ば 95\%の非超 過 確率が要求される場合には, 純出生 過程の方法を適用しらる構造物では平均応答スペクトル の 1.2 倍程度，応答包絡線の極值の方法を適用しうる 場合には 1.7 倍程度の最大応答に対して設計を行なえ ばよいことになる。この場合に参照する応答スペクトル は，前述の議論から，地震動の継続時間および卓越周期 によって分類されたものであるべきことはいらまでもな い。

\section{6. 結論}

本研究では, 構造物の最大地震応答の確率分布を不規 則振動論の立場から解析し，その結果に基づいて地震時 における構造物の最大応答の推定法を論じてきた。得ら れた成果を要約すれば次のとおりである。

（1）不規則地震動の確率モデルを導入し，等価継続 時間を用いることによって，振幅強度の非定常性につい て種々の特徴を有する地震動を統一的に比較する一つの 手法を示した。

（2）不規則地震動を受ける構造物の最大応答の確率

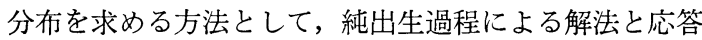
包絡線の極值による解法の二種の近似解法を考案した。

（3）これら二つの解法の結果とシミュレーションに 
よる数值帮験結果を比較検討することにより, 近似解の 精度と適肘範囲を明らかにした。その結果, 比較的短周 期の構造物汇定常的な地震動が作用する場合ほど純出生 過程による解法, 比較的長周期の構造物に衝撃的な地震 動が作用する場合ほど応答包絡線の極值による解法が優 れて抢り，両者を適宜選択適用することによって，かな り広いパラメーター領域で最大地震芯答の確率分布を求 めらることがわかった。

（4）最大応答の確率分布より求めた平均态答スペク トルに対する考察から，減衰定数が小さい長周期構造物 の平均最大応答は地震動の継続時間の影響を受けやすい こと, また応答スペクトルの形状は, 当然ながら地震動 の卓越周期にも影響されることを指摘した。

（5）最大応答の変動係数の特性加ら, 平均応答スペ クトルを耐震設計に忘用する場合, その結果得られる耐 震安全性を等しくするためには構造物の固有周期执よび 地震動の継続時間によって応答スペクトルの評価を変え る必要のあることを示し, 上述の二種の解法を適用しう る場合について，一定の非超過確率に対して選定すべき 許容最大応答の值を求めた。

本研究の成果を活用し, 確率統計的方法を耐震設計に 十分に取り入れうるまでには, 緒論で触れたような多く の問題が解決されるばならないとともに, 本研究で用い た手法についても, 地震動のモデルをより豊富にし,さ らに一般的な検討を加えること, 最大応答の確率分布に ついて, より広範なパラメーター領域での精度を検討す ることなどは今後の研究課題であるが, 少なくとも本研 究により, 構造物の最大地震応答に関するいくつかの特 性について，理論的裏付けを持った新たな説明を行ない 若干の有用な定量的資料を提供しえたと考えられる。

本研究の遂行に当り, 多くの適切な御指導上御討議を 賜わった京都大学 後藤尚男教授に染謝の意を表する次 第である。なお, 本研究の数值計算注すべて京都大学大 型計算機センターの FACOM 230-60によったことを付 記する。

\section{参 考 文 献}

1) Freudenthal, A.M., Garrelts, J.M. and Shinozuka, M. : The Analysis of Structural Safety, Proc. ASCE Vol. 92, ST 1, pp. 267-325, Feb., 1966.

2) Rosenblueth, E. and Bustamante, J.I. : Distribution of Structural Response to Earthquakes, Proc. ASCE, Vol. 88, EM 3, pp. 75-106, June, 1962.
3) Freudenthal, A.M. and Shinozuka, M. : Probabilyti of Structural Failure under Earthquake Acceleration, Trans. JSCE, No. 118, pp. 9-15, June, 1965.

4) Yamada, Y. and Takemiya, H. : Studies on the Statistical Aseismic Safety of Relatively Long Period Structures, Proc. JSCE, No. 172, pp. 63-78, Dec., 1969.

5) Davenport, A.G. : The Application of Statistical Concepts to the Wind Loading of Structures, Proc. IC E, Vol. 19, pp. 449-472, 1961.

6）小松定夫：長大吊橋の耐風設計法と安全性につ：て，土 木学会論文集, 142 号, fp. 10-19, 昭 42. 6 .

7）後藤尚男・电田弘行：地震㭙における最大地動の確菜論 的研究, 土木学会論文集, 159 号, pp. 1-12, 昭 43.11.

8) Goto, H. and Toki, K. : Structural Response to Nonstationary Random Excitation, Proc. IV WCEE, Vol. 1, pp. 130-144, 1969.

9）亀田弘行：地震時における構造物刀最大応答の確率分布 と平均床答スペクトルルついて, 土木学会算 25 回年次学 術講演会講演集, 第 1 部, pp. 509-512, 昭 45.11 .

10) Kameda, H. : Fundamental Studies on Probabilistic Methods of Structural Design to Resist Earthquakes, Doctoral Thesis submitted to Kyoto Univ., pp. 55147, March, 1971.

11) Kameda, H. : Probability Distribution of the Maximum Response of Structures Subjected to Nonstationary Random Earthquake Motion, Mem. Fac. Engng., Kyoto Univ., Vol. XXXII, pp. 243-280, Oct., 1971.

12) Caughey, T. K. and Stumpf, H. J. : Transient Response of a Dynamic System under Random Excitation, Jour. Appl. Mech., Ser. E, No. 4, pp. 449472, Dec., 1961.

13）後藤尚男・亀田弘行：構造物の不規則振動に㧍ける 最大 応答の確率分布について, 京都大学防災研究所年報, 11 号 A, pp. 239-253, 昭 43.3.

14）後藤尚男・亀田弘行：構造物の不规則振動になける最大 応答の確率分布について一定常入力に対与る過渡解一, 京都大学防災研究所年報, 12 号 A, pp. 289-299, 昭.44. 3.

15) Rice, S.O. : Mathematical Analysis of Random Noise, Selected Papers on Noise and Stochastic Processes, edited by N. Wax, Dover, pp. 133-294, 1954.

16）後藤尚男・土岐憲三・横山康夫・龟田弘行・秋吉 卓 $\cdot$ 石 田昌弘：松代群発地震地域における 霹動観測結果につい $\tau$, 土木学会論文集, 145 号, pp. 1-11, 昭.42.9.

17）栗林栄一・岩崎敏男・辻 勝成：地震空答スペクトルに及 添す諸因子, 第 11 回地震工学研究発表会講演蔇要, 土木 学会, pp. 71-74, 昭.46.7.

18) Katayama, $\mathrm{T}: \mathrm{A}$ Note on the Acceleration Ratio Spectrum of Seventy Japanese Strong-Motion Earthquake Records, Bull. Fac. Sci. \& Engng., Chuo Univ., Vol. 12, pp. 7-18, Dec., 1969.

(1971.9.20 - 受付) 